\title{
PENINGKATAN PERILAKU ASERTIF MELALUI BIMBINGAN KELOMPOK TEKNIK SOSIODRAMA
}

\author{
Sedyawati \\ SMP Negeri 6 Malang \\ dyahsedyawati83@gmail.com
}

\begin{abstract}
Abstrak
Penelitian ini bertujuan untuk meningkatkan perilaku asertif siswa melalui bimbingan kelompok menggunakan teknik sosiodrama. Perilaku asertif adalah ketrampilan mengungkapkan pikiran dan perasaan secara baik, jujur dan terbuka. Dengan menjadi asertif, siswa dapat mengungkapkan pendapatnya dengan jujur dan terbuka, mempertahankan pendapatnya tanpa merendahkan pendapat oranglain, mampu menolak ajakan teman dengan baik, menegur teman yang salah dan berkata jujur. Rancangan penelitian yang digunakan adalah Penelitian Tindakan Kelas (PTK). Tindakan yang dilaksanakan dalam penelitian ini adalah pemberian layanan bimbingan kelompok teknik sosiodrama, yaitu pemberian layanan bimbingan kepada sekelompok individu dengan cara bermain peran guna memecahkan masalah yang dialaminya yaitu kurangnya berperilaku asertif. Hasil penelitian menunjukkan peningkatan perilaku asertif sebesar $49 \%$ pada masing-masing subjek pada siklus I. Setelah diberikan tindakan kembali pada siklus II masing-masing subjek mengalami peningkatan sebesar rata-rata $82 \%$. Hal tersebut menunjukkan perilaku asertif yang rendah dapat meningkat secara signifikan jika diberikan tindakan pada siklus I dan II. Peningkatan ini disebabkan selama ini siswa belum mengetahui apa perilaku asertif dan bagaimana cara berperilaku asertif, setelah dilatihkan melalui bimbingan kelompok menjadi tahu apa itu perilaku asertif dan bagaimana cara bersikap asertif. Melalui pelatihan asertif dengan temannya melalui bimbingan kelompok teknik sosiodrama, siswa dapat secara langsung menganalisa perilaku asertif. Siswa dapat secara langsung merasakan manfaat layanan yaitu dapat menerapkan cara berperilaku asertif sehingga ketrampilan tersebut dapat diterapkan dalam kehidupan sehari-hari. Keberhasilan layanan bimbingan kelompok teknik sosiodrama menunjukkan bahwa sosiodrama tepat digunakan dalam memberikan pemahaman tentang penerapan perilaku asertif.
\end{abstract}

Kata Kunci: perilaku asertif, bimbingan kelompok, sosiodrama

\section{PENDAHULUAN}

Sesuai denganPeraturan MenteriPendidikan dan Kebudayaan Nomor 111 tentang Bimbingan dan Konseling pada Pendidikan Dasar dan Menengah, Layanan Bimbingan dan Konseling memiliki tujuan membantu siswa mencapai perkembangan optimal dan kemandirian secara utuh dalam aspek pribadi, belajar, sosial dan karier. Karena itulah Bimbingan dan konseling di sekolah memiliki peranan penting dalam membantu peserta didik dalam mencapai tugas-tugas perkembangan sebagaimana tercantum dalam Standar Kompetensi Kemandirian Peserta Didik (SKKPD). Dalam upaya mendukung pencapaian tugas perkembangan tersebut, program Bimbingan dan Konseling dilaksanakan secara utuh dan kolaboratif dengan seluruh stakeholder sekolah.
Layanan Bimbingan dan Konseling yang diselenggarakan oleh SMP Negeri 6 Malang memiliki banyak tantangan, khususnya dari problematika yang dialami oleh sebagian besar siswa bersifat kompleks. Berdasarkan data hasil observsi yang dilakukan peneliti dan wawancara kepada rekan sejawat, masalah yang seringkali dialami peserta didik diantaranya adalah problem terkait penyesuaian akademik di sekolah, penyesuaian diri dengan pergaulan sosial di sekolah, ketidakmatangan orientasi pilihan karir, dan lainlainnya. Dalam hal pergaulan sosial di sekolah yang baru-baru ini terjadi berdasarkan hasil wawancara adalah pengeroyokan salah satu peserta didik yang disebabkan tidak mampunya menyatakan isi hati dalam bentuk komunikasi yang efektif dengan 
oranglain sehingga timbul kesalahpahaman dalam pergaulan. Kesalahpahaman terjadi tidak hanya dengan teman tapi juga seringkali dengan guru sehingga membuat kenyaman belajar mengajar menjadi terganggu.

Pada umumnya dalam pergaulan dengan teman sebayanya, seorang remaja cenderung diam, hal ini bisa saja terjadi karena kecemasan tidak bisa diterima oleh kelompoknya. Menurut Calhoun (1990), orang yang berperilaku asertif mampu menyatakan "Inilah saya. Saya perlu diperhitungkan Saya mempunyai hak untuk menjadi seperti yang saya inginkan, serta saya akan menjalankan semua keputusan saya". Kemampuan asertif sangat diperlukan oleh siswa, karena apabila tidak memiliki perilaku asetif maka ia akan menjadi individu yang tidak bebas, selalu dibawah kekuasaan atau tekanan orang lain dan selalu menuruti oranglain tanpa memeperdulikan dirinya.

Berdasarkan pengamatan dari peneliti dan wawancara dengan guru mata pelajaran serta Kesiswaan kurangnya perilaku asertif ditunjukkan siswa di SMP Negeri 6 Malang adalah ada beberapa anak yang masih ikut-ikutan temannya dalam memilih kegiatan ekstrakurikuler, ikut-ikutan ke kantin saat kegiatan mandiri, ikut-ikutan tidak sholat berjamaah saat teman di kelompoknya tidak sholat, ikut-ikutan membuka HP saat gurunya tidak mengawasi dll. Dalam kegiatan di kelas pun masih kurang aktif terlibat KBM dan kurang aktif bertanya jika ada materi/soal yang belum jelas.

Berdasarkan analisis yang dilakukan peneliti melalui Daftar Cek Masalah tahun 2018 halaman 13 sd 16 pada butir-butir pernyataan yang sesuai dengan perilaku asertif dapat ditarik kesimpulan bahwa perilaku asertif Kelas VIII.2 masih cukup rendah. Siswa belum bisa mengungkapkan apa yang dirasaknnya secara jujur dan terbuka, merasa kurang bersemangat, sering merasa malu bergaul dengan lawan jenis, bersikap kaku dan tidak toleransi, mudah tersinggung, merasa malu berhadapan dengan orang banyak, sering tidak sabar, sering ditegur karena kurang sopan, belum berani mengambil keputusan secara tegas dan kurang bisa menyatakan "ya" atau "tidak" sesuai keinginan hatinya.
Apabila hal ini dibiarkan maka akan menimbulkan masalah-masalah baru yang beruntun yang akan dihadapi siswa. Masalah-masalah yang timbul dapat antara lain mudah cemas, kurang percaya diri, sering tertekan dan tidak nyaman bergaul dengan temannya karena kurang bisa mengungkapkan keinginan hatinya. Hal ini dapat berdampak luas pada prestasi akademik yang menurun dan perkembangan potensi siswa menjadi terhambat.

Berdasarkan kondisi tersebut, maka diperlukan tindakan untuk melatih perilaku asertif siswa melalui layanan yang diberikan oleh guru BK. Guru BKdi sekolah yang bertugas memfasilitasi perkembangan siswa di sekolah memiliki empat komponen program diantaranya layanan dasar, layanan peminatan dan perencanaan individual, layanan responsif, dan dukungan sistem. Melalui metode dan teknik yang digunakan secara tepat diharapkan mampu membantu mengatasi segala permasalahan yang dihadapi siswa. Bimbingan kelompok teknik sosiodrama yang termasuk dalam layanan dasar adalah layanan bimbingan konseling yang cocok digunakan dalam menyelesaikan masalah sosial. Romlah (2001) menerangkan bahwa sosiodrama adalah permainan peranan yang ditujukan untuk menyelesaikan masalah sosial yang timbul dalam hubungan antar manusia.

Penelitian yang dilakukan oleh Dewi (2016) tentang Pengaruh Layanan Bimbingan Kelompok Teknik Sosiodrama terhadap Perilaku Asertif Siswa Kelas IX SMP Negeri 25 Semarang Tahun Pelajaran 2015/2016 menunjukkan setelah diberikan layanan bimbingan kelompok metode sosiodrama perilaku asertif peserta didik berada dalam kategori tinggi. Berdasarkan pada beberapa penelitian tersebut, perilaku asertif siswa dapat ditingkatkan dengan memberikan layanan bimbingan kelompok teknik sosiodrama.

Dengan bimbingan kelompok teknik sosiodrama peserta didik dapat belajar bagaimana terlibat aktif dalam dinamika kelompok, berpendapat dengan jujur dan terbuka, menghargai pendapat oranglain, tidak memaksakan kehendak dan menyampaikan pendapatnya, isi hatinya, 
keinginannya dengan cara-cara yang baik. Siswa akan dilatih bagaimana berperilaku asertif dengan memainkan peran tertentu sehingga terasa lebih nyata, langsung dan terbuka. Hal tersebutlah yang mendasari peneliti melakukan penelitian dengan judul "UpayaPeningkatan Perilaku Asertif melalui Bimbingan Kelompok Teknik Sosiodrama siswa Kelas VIII.2 SMP Negeri 6 Malang".

Permasalahan yang diangkat dari penelitian ini adalah apakah bimbingan kelompok teknik sosiodrama dapat meningkatkan ketrampilan asertif siswa Kelas VIII.2? SMP Negeri 6 Malang. Tujuan dari penelitian ini adalah untuk mendeskripsikan bahwa bimbingan kelompok teknik sosiodrama dapat meningkatkan ketrampilan asertif siswa Kelas VIII.2 SMP Negeri 6 Malang.

Menurut Gunarsa (dalam Dewi, 2016) perilaku asertif adalah perilaku antar-perorangan (interpersonal) yang melibatkan aspek kejujuran dan keterbukaan pikiran dan perasaan. Menurut Sugiyo (2005: 108), assertiveness adalah orangorang yang tegas dalam mengambil keputusan. Ketegasan merupakan suatu bentuk sikap dan perilaku seseorang yang menunjukkan beberapa sifat seperti:

1) Perilaku yang mampu membuat individu mampu bertindak dengan caranya sendiri tetapi juga tidak menutupi dari saran orang lain yang menjadikan dirinya lebih baik. 2) Mampu menyuarakan hak-haknya tanpa menyinggung orang lain. 3) Percaya diri, mengekspresikan diri secara spontan (pikiran dan perasaan) banyak dicari dan dikagumi oranglain. Sugiyo $(2005: 112)$

Menurut Corey (2010) perilaku asertif adalah ekspresi langsung, jujur pada tempatnya dari pikiran, perasaan, kebutuhan atau hak-hak seseorang tanpa kecemasan yang beralasan.

Berdasarkan pengertian para ahli tersebut dapat disimpulkan perilaku asertif adalah keterampilan mengungkapkan pikiran dan perasaan secara baik, jujur dan terbuka. Dengan menjadi asertif, siswa akan dapat mengungkapkan pendapatnya dengan jujur dan terbuka, mempertahankan pendapatnya tanpa merendahkan pendapat oranglain, mampu menolak ajakan teman dengan baik, menegur teman yang salah dan berkata jujur.

Sedangkan bimbingan kelompok menurut Sukardi (2008) adalah layanan bimbingan yang memungkinkan sejumlah siswa secara bersamasama memperoleh berbagai bahan dari narasumber tertentu. Dengan berlatih berperilaku asertif melalui layanan bimbingan kelompok, diharapkan siswa dapat terhindar dari konflik dengan teman sebaya, guru, orangtua maupun lingkungannya. Dengan demikian siswa dapat mengembangkan dirinya secara optimal dan dapat mengatasi hambatan yang dijumpai dalam hidupnya. Perilaku asertif dapat dilatihkan melalui bimbingan kelompok.

\section{METODE}

Rancangan penelitian yang digunakan adalah Penelitian Tindakan Bimbingan dan Konseling (PTBK) karena bidang yang diteliti adalah Bimbingan Konseling dan peneliti adalah Guru Bimbingan Konseling. Tindakan yang dilaksanakan dalam penelitian ini adalah pemberian layanan bimbingan kelompok teknik sosiodrama, yaitu pemberian layanan bimbingan kepada sekelompok individu dengan cara bermain peran guna memecahkan masalah yang dialaminya yaitu kurangnya berperilaku asertif

Subyek penelitian ini adalah siswa Kelas VIII.2 SMP Negeri 6 Malang Tahun Pelajaran 2017/2018 berjumlah 10 anak, yaitu MH, IM, LFP, AZF, SDA, AS, FIA, MAY, DMS dan HZA. Waktu dilaksanakannya penelitian ini pada semester genap, pada tanggal 1 April sd. 03 Mei 2018. Tempat diadakannya penelitian di SMP Negeri 6 Malang, Jl. Kawi 15A Malang, Kelurahan Bareng, Kecamatan Klojen, Kota Malang.

Perencanaan tindakan dalam penelitian ini direncanakan dalam beberapa siklus. Model penelitian yang digunakan adalah model penelitian Kemmis dan MC. Taggart (dalam Arliani, 2014) yaitu model penelitian yang terdiri dari empat komponen: 1) perencanaan (planning), 2) tindakan (acting), 3) pengamatan (observing), 4) refleksi (reflecting) 
Dalam penelitian ini, sebelum dan sesudah melaksanakan tindakan diperlukan alat pengumpul data. Data yang diteliti dalam penelitian ini adalah data tentang perilaku asertif yang dimiliki oleh siswa. Data dalam penelitian ini mencakup data perilaku asertif yang diperoleh melalui angket/ skala asertif, data hasil observasi dan data hasil wawancara. Sumber data yang digunakan dalam penelitian ini adalah subyek penelitian Kelas VIII.2, yaitu 10 anak yang terindikasi kurang berperilaku asertif dan observer/pengamat/rekan sejawat Guru BK/ Shinta Amelia, S.Pd.

Keefektifan tindakan yang telah dilakukan peneliti dianalisis melalui tahapan: 1) Reduksi yang dilakukan dengan mengecek dan mencatat kembali data-data yang telah terkumpul, 2) Interpretasi atau menafsirkan data yang diwujudkan dalam bentuk pernyataan, 3) Inferensi yaitu menyimpulkan apakah dalam pemberian layanan ini telah terjadi peningkatan dalam berperilaku yang diinginkan, 4) Tindak Lanjut yaitu langkah-langkah perbaikan untuk siklus berikutnya atau dalam pelaksanaan di lapangan setelah siklus berakhir berdasarkan inferensi yang telah ditetapkan dan 5) Kesimpulan yang diambil berdasarkan analisis hasil observasi yang disesuaikan dengan tujuan penelitian ini. Kemudian dituangkan dalam bentuk interpretasi dalam bentuk pernyataan.

\section{HASIL DAN PEMBAHASAN}

Sebelum melaksanakan tindakan, peneliti terlebih dahulu mengadakan pratindakan berupa survey awal terhadap peserta didik yang akan dijadikan subyek penelitian. Kegiatan ini berfungsi untuk mempermudah peneliti melakukan tindakan bimbingan pada siklus I. Survei awal tersebut dilaksanakan pada awal April dengan cara wawancara dengan guru mata pelajaran, wali kelas dan Urusan Kesiswaan. Disamping itu peneliti juga melakukan studi dokumen pada Buku Pribadi Peserta Didik. Survei awal ini juga didukung oleh Guru BK yang juga membina kelas yang akan digunakan sebagai subyek penelitian jadi benar-benar mengetahui keadaan kelas yang akan digunakan dalam penelitian.
Hasil observasi, wawancara dan studi dokumen yang dilakukan dalam Kelas VIII.2 teridentifikasi 10 anak kurang memiliki perilaku asertif. Langkah selanjutnya yaitu melakukan pretest dengan menggunakan angket perilaku asertif yang ditujukan kepada 10 snak tersebut. Angket tersebut digunakan sebagai cara atau teknik untuk memastikan siswa yang mendapat prioritas utama untuk diberikan layanan bimbingan kelompok teknik sosiodrama. Adapun hasil angket pretest digambarkan dalam grafik sebagai berikut:

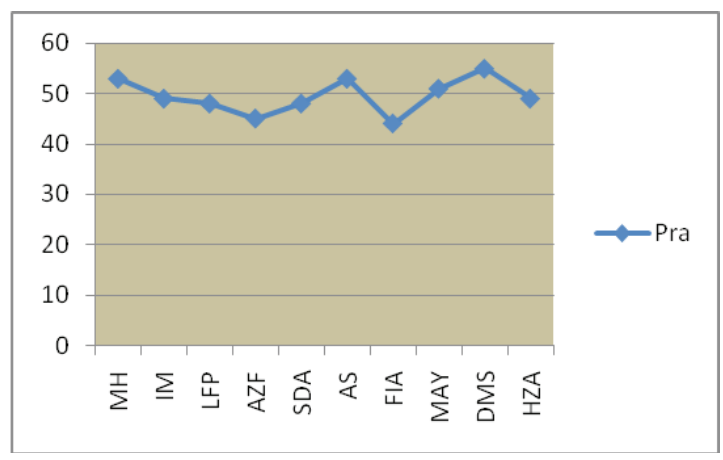

Grafik 4.2 Hasil Pre Test

Berdasarkan grafik tersebut, diketahui hasil skor perilaku asertif menunjukkan skor IM, LFP, AZF, SDA, FIA dan HZA lebih rendah disbanding ke empat teman lainnya, yaitu MH, AS, MAY dan DMS. Hal ini menunjukkan bahwa siswa masih belum bisa berperilaku asertif dengan baik. Perilaku asertif siswa menunjukkan bahwa indikator dalam berperilaku asertif belum terpenuhi dengan baik. Karena itulah perlu diberikan layanan tindakan bimbingan kelompok metode sosiodrama agar indicator dalam perilaku asertif dapat terpenuhi dengan baik.

Berdasarkan pengamatan pada siklus I menunjukkan bahwa peserta didik memiliki kemampuan yang cukup dalam mendengarkan instruksi peneliti. Kegiatan sosiodrama berjalan dengan baik, hal ini ditunjukkan dengan keaktifan peserta dalam kegiatan, ketepatan memperagakan tokoh-tokoh yang diperankan dalam skenario. Beberapa peserta dapat mengungkapkan pendapatnya dengan baik, sedangkan beberapa peserta yang lain ada yang masih malu-malu dalam memerankan naskah sosiodrama yang sudah diberikan. 
Berdasarkan hasil wawancara pada siklus I yang ditujukan pada 3 (tiga) peserta menunjukkan bahwa 1 (satu) peserta dapat mengikuti jalannya sosiodrama dengan baik dan dapat mengikuti serta menjalankan peran dengan baik. Disamping itu, dia juga mampu memperoleh manfaat dari sosiodrama yang telah diperankannya tadi. Namun (2) dua diantaranya masih belum dapat mengambil manfaat dari naskah drama yang telah diperankannya meskipun sudah mengikuti proses sosiodrama.

Pada tanggal 06 April 2018, peneliti memberikan angket kepada peserta didik sebelum diberi tindakan layanan. Dan angket kedua diberikan setelah dilaksanakannya setelah siklus 1 atau setelah diberikannya tindakan. Tujuannya adalah untuk mengetahui hasil pelaksanaan tindakan layanan Bimbingan Kelompok teknik Sosiodrama. Berdasarkan hasil skor pretest dan skor posttest siklus I diperoleh hasil sebagai berikut:

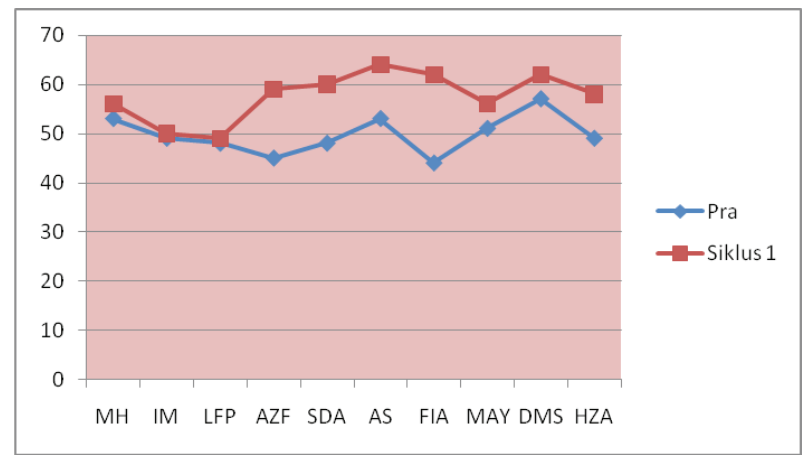

Grafik 4.3 Perbandingan Hasil Pre test dan Siklus 1

Berdasarkan pada grafik perbandingan tersebut, dapat disimpulkan adanya peningkatan berperilaku asertif yang dialami masing-masing subyek. Namun ada beberapa subyek, seperti IM dan LFP yang tidak mengalami peningkatan yang signifikan, sehingga diperlukan tindakan layanan siklus II.

Berdasarkan pengamatan pada siklus II menunjukkan bahwa peserta didik memiliki kemampuan yang baik dalam mendengarkan instruksi peneliti. Kegiatan sosiodrama berjalan dengan baik, hal ini ditunjukkan dengan keaktifan peserta dalam mengikuti kegiatan, keaktifan berdiskusi dalam mengembangkan naskah sosiodrama sebelum memerankan, ketepatan memperagakan tokoh-tokoh yang diperankan dalam skenario. Hampir semua peserta dapat mengungkapkan pendapatnya dengan baik dan dapat memperagakan tokoh yang diperankannya dengan baik.

Berdasarkan hasil wawancara pada siklus II yang ditujukan pada 3 (tiga) peserta menunjukkan bahwa ketiga peserta tersebut dapat mengikuti jalannya sosiodrama dengan baik dan dapat mengikuti serta menjalankan peran dengan baik. Disamping itu, mereka juga mampu memperoleh manfaat dari sosiodrama yang telah diperankannya tadi.

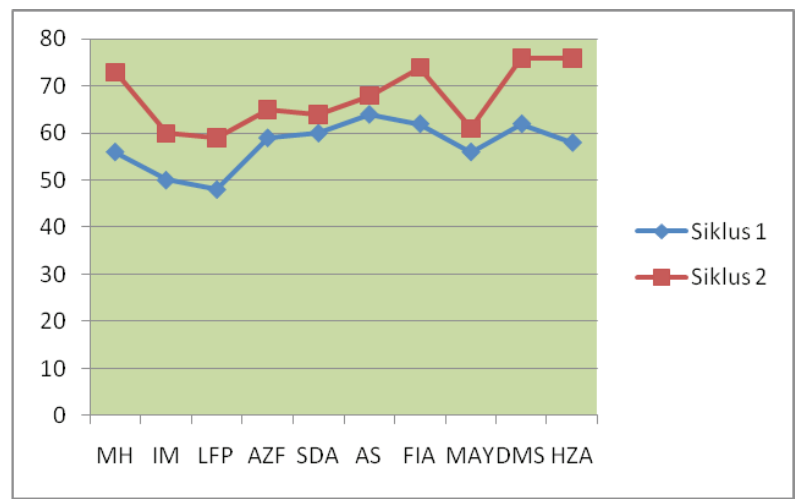

Grafik 4.4 Perbandingan hasil siklus $1 \& 2$

Berdasarkan pada grafik perbandingan tersebut, dapat disimpulkan adanya peningkatan berperilaku asertif yang dialami masing-masing subyek. Perbandingan hasil tindakan pada siklus I dan siklus II telah telah diperoleh dengan perubahan hasil baik. Berdasarkan dari hasil analisis dan refleksi tiap siklus, dapat diketahui bahwa untuk mencapai perubahan perilaku asertif secara signifikan dibutuhkan 2 siklus, yaitu siklus I dan siklus II. Perubahan tersebut dapat digambarkan sebagai berikut: 
Tabel 1.1 Perbandingan Skor Pre Test, Siklus I \& Siklus II

\begin{tabular}{ccccccc}
\hline No & Nama & Skor Pretes & Skor siklus 1 & Skor siklus 2 & $\begin{array}{c}\text { Persentase perubahan } \\
\text { siklus 1 }\end{array}$ & $\begin{array}{c}\text { Persentase perubahan } \\
\text { siklus 2 }\end{array}$ \\
\hline 1 & MH & 53 & 56 & 73 & $52 \%$ & $77 \%$ \\
\hline 2 & IM & 49 & 50 & 60 & $48 \%$ & $83 \%$ \\
\hline 3 & LFP & 48 & 49 & 59 & $47 \%$ & $83 \%$ \\
\hline 4 & AZF & 45 & 59 & 65 & $44 \%$ & $91 \%$ \\
\hline 5 & SDA & 48 & 60 & 64 & $47 \%$ & $94 \%$ \\
\hline 6 & AS & 53 & 64 & 68 & $52 \%$ & $84 \%$ \\
\hline 7 & FIA & 44 & 62 & 74 & $43 \%$ & $82 \%$ \\
\hline 8 & MAY & 51 & 56 & 61 & $50 \%$ & $76 \%$ \\
\hline 9 & DMS & 55 & 62 & 76 & $54 \%$ & \\
\hline 10 & HZA & 49 & 58 & 76 & $48 \%$ & \\
\hline
\end{tabular}

Berdasarkan perbandingan skor tersebut menunjukkan bahwa masing-masing subyek penelitian mengalami peningkatan kemampuan berperilaku asertif dengan peningkatan ratarata sebesar $49 \%$ pada siklus I dan mengalami peningkatan pada siklus II sebesar rata-rata $82 \%$.

Pemberian layanan melalui teknik sosiodrama dianggap tepat dalam upaya meningkatkan perilaku asertif siswa, mengingat metode ceramah saja kurang mampu meningkatkan perilaku asertif siswa secara signifikan.

Menurut Corey (2010) bahwa fokus latihan asertif adalah mempraktekkan melalui permainan peran, kecakapan-kecakapan bergaul yang baru diperoleh sehingga individu-individu diharapkan mampu mengatasi ketidak memadainya dan belajar bagaimana mengungkapkan perasaan-perasaan dan pikiran-pikiran mereka secara lebih terbuka disertai keyakinan bahwa mereka berhak menunjukkan reaksi-reaksi yang terbuka itu.

Dengan bimbingan kelompok teknik sosiodrama siswa dapat belajar bagaimana terlibat aktifdalam dinamika kelompok, berpendapat dengan jujur dan terbuka, menghargai pendapat oranglain, tidak memaksakan kehendak dan menyampaikan pendapatnya, isi hatinya, keinginannya dengan cara-cara yang baik. Hal-hal tersebut dapat melatih peserta didik berperilaku asertif.

Hal tersebut ditunjukkan pada hasil analisis angket yaitu skor perilau asertif yang rendah telah dapat meningkat secara signifikan pada siklus I dan
II. Siswa dapat secara langsung merasakan manfaat layanan yaitu dapat secara langsung mempraktekkan cara berperilaku asertif sehingga ketrampilannya itu dapat diterapkan dalam kehidupan seharihari. Hal ini sejalan dengan pendapat Brown (dalam Ratnasari, 2014) yang menyatakan bahwa sosiodrama adalah metode belajar yang menciptakan pemahaman mendalam mengenai sistem sosial yang membentuk kita secara individu maupun kolektif.

Berdasarkan penjelasan diatas dapat disimpulkan bahwa teknik sosiodrama tepat digunakan untuk melatih ketrampilan yang dibutuhkan dalam pergaulan dengan sesama manusia atau teman sebaya. Salah satunya adalah ketrampilan berkomunikasi secara jujur, terbuka, bertanggungjawab dan menghargai oranglain. Melalui teknik sosiodrama, Guru BK mengajarkan perilaku yang berkualitas dalamberhubungan dengan teman sebaya. Siswa yang ditunjuk memerankan peran yang telah disusun dalam naskah sosiodrama dapat memahami cara-cara berkomunikasi yang baik, jujur, terbuka, bertanggungjawab dan menghargai oranglain. Dengan demikian siswa memiliki ketrampilan sosial yang dibutuhkannya dalam pergaulan.

Keterampilan sosial dalam pertumbuhan sosial remaja sangat penting, keterampilan sosial mencakup kemampuan untuk membangun pertemanan, bertemu dan berbau dengan lingkungan, berkomunikasi serta mempertahankan hubungan pertemanan yang sudah dibangun. Keterampilan sosial dipengaruhi oleh faktor pertemanan dan 
komunikasi. Pertemanan diasosiasikan dengan penerimaan teman sebaya. Faktor komunikasi adalah kemampuan remaja dalam menyampaikan pendapat dan keinginan dirinya dengan nyaman, jujur dan tidak menyinggung orang lain. Komunikasi berhubungan dengan perilaku asertif yang menghendaki komunikasi yang baik, jujur, terbuka, bertanggungjawab dan menghargai orang lain.

\section{SIMPULAN}

Berdasarkan hasil penelitian yang telah dilaksanakan disimpulkan bahwa bimbingan kelompok teknik sosiodrama dapat meningkatkan perilaku asertif siswa Kelas VIII.2. Sesuai dengan hasil analisis data pada Penelitian Tindakan Kelas menggunakan bimbingan kelompok teknik sosiodrama pada siklus I menunjukkan peningkatan perilaku asertif sebesar $49 \%$ pada masing-masing subyek. Setelah diberikan tindakan kembali pada siklus II masing-masing subyek mengalami peningkatan sebesar rata-rata $82 \%$. Hal tersebut menunjukkan perilaku asertif yang rendah dapat meningkat secara signifikan jika diberikan tindakan pada siklus I dan II. Tindakan yang dilakukan Guru BK adalah melaksanakan bimbingan kelompok teknik sosiodrama. Melalui sosiodrama, siswa dapat secara langsung merasakan manfaat layanan yaitu dapat mempraktekkan cara berperilaku asertif sehingga ketrampilan tersebut dapat diterapkan dalam kehidupan sehari-hari. Keberhasilan layanan bimbingan kelompok teknik sosiodrama menunjukkan bahwa sosiodrama tepat digunakan dalam meningkatkan perilaku asertif siswa.

\section{DAFTAR PUSTAKA}

Arliani, Lina. (2014). Bimbingan Kelompok Teknik Sosiodrama Untuk Meningkatkan Perilaku Asertif Antar Sebaya Siswa Kelas IX SMP Negeri 1 Nguter Tahun Pelajaran 2013/2014. Skripsi: UNS

Calhoun, James F. (1990). Psikologi tentang Penyesuaian dan Hubungan Kemanusiaan. Penerjemah: Prof. Dr. Ny. Satmoko., R.S.

Corey, Gerald. (2010). Teori dan Praktik Konseling \& Psikoterapi. Bandung: Refika Aditama
Dewi, Karlina. (2016). Pengaruh Layanan Bimbingan Kelompok Teknik Sosiodrama terhadap Perilaku Asertif Siswa Kelas IX SMP Negeri 25 Semarang Tahun Pelajaran 2015/2016. Skripsi: Universitas Negeri Semarang

Kemendikbud. (2014). Permendikbud Nomor 111 tentang Bimbingan Konseling pada Pendidikan Dasar dan Menengah. Jakarta: Kemendikbud

Ratnasari, Novita Dian. (2014). Upaya Peningkatan Komunikasi Asertif melalui Layanan Bimbingan Pribadi-Sosial menggunakan Metode Sosiodrama. Skripsi: Universitas Sanata Dharma

Romlah, Tatik.(2001). Teori dan Praktik Bimbingan Kelompok. Malang: Universitas Negeri Malang

Sugiyo. (2005). Komunikasi Antar Pribadi. Semarang: Unnes Press

Sukardi, Dewa Ketut. (2008). Pengantar Pelaksanaan Program Bimbingan dan Konseling di Sekolah. Jakarta: Rineka Cipta 